\title{
Liberal Nationalism and the Challenge of Masculinity Studies in Quebec
}

\section{Jeffery Vacante}

In the last three decades Quebec nationalism has come to be regarded by many observers both inside and outside Quebec as virtually synonymous with liberalism. This impression rests upon a particular interpretation of the Quiet Revolution as a liberal moment when French-speaking Quebecers finally left behind their political and social conservatism and embraced a civic and pluralistic version of nationalism, and when the state emerged as the primary instrument for implementing a social democratic agenda. ${ }^{1}$ According to the political scientist Kenneth McRoberts, "the Quiet Revolution represented a new departure for Quebec: the combining of nationalism with liberalism."' This view has become so entrenched in the Quebec imagination that nationalism has come to be seen as the only means of safeguarding liberalism in the province. According to some historians, the fate of Quebec's liberal traditions depends entirely upon the province's ability to achieve greater independence from Canada. Michel Sarra-Bournet, for example, notes that failure to achieve independence reinforces a defensive brand of nationalism. " $\mathrm{C}$ 'est lorsqu'il n'a pu trouver d'expression politique que le nationalisme s'est réfugié dans les bastions culturel et linguistique," he writes, warning, "la non-résolution de la question nationale au Québec comporte le danger d'un retour au nationalisme ethnique." "3 Gérard Bouchard agrees, wondering, "en l'absence de la souveraineté, quels sont donc les modèles de rechange qui permetteraient d'éviter un retour en force de l'ethnicité, un nouveau repli sur la survivance, un relance de revendications stériles auprès du governement canadien, le renonciation au rêve d'ouverture et d'émancipation d'une francophonie originale en territoire québécois?"4

Some politicians have also stressed the ties between liberalism and nationalism in their efforts to drum up support for Quebec independence. Former Quebec premier Lucien Bouchard, for example, claimed in the days leading up to the 1995 referendum that "un oui conservera intacte la flamme de générosité animant les Québécois. Ce cera aussi une digue qui va nous protéger contre la tentation de la droite." Others have pointed to the rightward drift in English Canada to shore up support from labour unions and to warn the population that the province's social democratic agenda is threatened as long as it remains a part of Canada. ${ }^{6}$ One need only look at the opposition that Premier Jean Charest has encountered as he attempts to reduce the size of the Quebec government and to introduce some of those neo-conservative measures most often associated with Ontario and Alberta. The former labour union leader Gérald Larose, for one, has described the premier's conservative agenda as "foreign" to Quebec

96

(C) Left History

11.2 (Fall 2006) 
sensibilities. ${ }^{7}$ Such comments reinforce the impression that nationalism, and even Quebec identity, is inextricably intertwined with liberalism.

But the idea that modern Quebec nationalism is defined by its liberalism is complicated by a second assumption about its meaning. Since the $1960 \mathrm{~s}$, Quebec nationalism has also been seen as an instrument capable of revitalizing manhood in the province by providing French-speaking men with the necessary tools to reclaim their economic power. The journalist Mathieu-Robert Sauvé suggested recently that the movement for Quebec independence that emerged in the 1960s was largely a men's movement, writing, "l'idée d'indépendance a été une idée d'hommes. Non pas que les femmes n'y aient pas adhéré et qu'elle n'aient pas été d'excellentes ambassadrices de la cause ... Peut-être étaient-elles derrière leurs pères, leurs maris, leurs frères, comme sources d'inspiration ou éminences grises, peut-être ont-elles poussé leurs hommes à l'action politique ... mais elles ne furent pas en avant de la scène." "The poet and critic Pierre Nepveu has noted that "la Révolution tranquille est d'abord une histoire de fils orphelins qui se cherchent non pas une mère mais, presque désespérément, une identification paternelle." While nationalist leaders today rarely call explicitly for revitalized manhood, their arguments continue to suggest that full provincial autonomy is necessary before men can exercise the full political, economic, and social power that is usually associated with that manhood.

The idea that Quebec nationalism could serve both as an instrument to empower men and to promote the pluralistic and egalitarian values associated with liberalism has been challenged in recent years. Feminist writers like Diane Lamoureux have recognized the limits of nationalism, pointing out that it "has always held a misogynous view of women."10 The emergence of masculinity studies as an academic field over the last number of years threatens to further erode the link between liberalism and nationalism in the province because the best of that writing would, like feminist writing before it, implicate the Quebec state in a misogynistic program to oppress women and thus threaten the very idea that the state represents a liberal tool for progress. That is to say, if the Quebec state is shown to be illiberal and complicit in the oppression of women, then it becomes much more difficult to regard Quebec nationalism as a completely liberal movement. The notion that the Quiet Revolution transformed the province into a modern society that embraced a liberal form of nationalism, then, would need to be reconsidered because that very same nationalism was and is being used to fulfil French-speaking Quebec men's desires for greater economic and political power.

The link between national affirmation and manhood was evident in the decades before the Quiet Revolution. During the 1930s many Quebec reformers were concerned that French-speaking Quebecers appeared unable to excel in an economy dominated by English Canadians. These reformers called on the state to arrest what they claimed were feelings of inadequacy on the part of 
French-speaking men arising from an inability to compete with EnglishCanadian men. In calling on the state to take control of education from the Church, for example, they argued that the Church was no longer capable of producing "virile" men who could take on the challenges of the industrial workplace. Victor Barbeau, a writer and professor at the École des Hautes Études Commerciales, claimed that the Church-run schools were destroying the province's men with an "emasculating" curriculum that "proletarianized" and "devirilized" students and that "étouffe, détruit toute personnalité."” By measuring a man's worth by his ability to exercise economic power in an urban and industrial environment defined by secular institutions, Barbeau and other critics were also challenging older notions of manhood that rested on piety and agrarian values. ${ }^{12}$

By the 1950s, a number of intellectuals drew more explicit links between Quebec manhood and the province's political "liberation" from Canada. Drawing on the rhetoric of the post-war anti-colonial movement, they wrote of the need to free the province from the shackles of its humiliating and "emasculating" dependence on Ottawa, and turned to Quebec independence as a means of reasserting the manhood that had been lost under their "colonial" arrangement. ${ }^{13}$ According to the literary critic Patricia Smart, "the revolutionary project is that of a son rebelling against the mother and seeking a 'virility' seemingly achievable only at women's expense." ${ }^{14}$ Katherine A. Roberts, too, shows the ways in which the colonized state came to be associated with emasculation and feminine dependence, and that "the movement towards decolonisation involves the desire for full masculinity and the concomitant destruction of one's femininity." ${ }^{15}$ Or, as Mary Jean Green puts it, "the image of the newly decolonised subject [w]as a virile, heterosexual man."16 Many Quebec nationalists have also defined their own heterosexual virility according to their ability to lead the province out of its figurative state of homosexual weakness and dependence within Canadian federalism. ${ }^{17}$ The rhetoric of decolonization that many nationalists appropriated in the 1960s, Robert Schwartzwald writes, was infused with "homophobic tropes" whereby "those found to be traitors or sell-outs to the cause of national revolution are gendered as passive/seductive men." 18 In addition to reversing almost two centuries of humiliation and subservience within the "colonial" shackles of the federal state, then, the push for "decolonization" and subsequent calls for independence came to be seen as necessary steppingstones to achieving full manhood.

While the nationalist rhetoric of the 1960 s was infused with calls for masculine emancipation, it nonetheless appealed to a number of women who were searching for their own liberation. According to Diane Lamoureux, in fact, a number of women found the language of nationalism to be useful because it offered them "a political vocabulary with which they could analyze their oppression." ${ }^{\prime 19}$ In 1969, some women who embraced this rhetoric of liberation 
established the Front de Libération des Femmes (FLF) to fight for women's emancipation alongside Quebec independence. The FLF approached the liberation of women as part of a larger revolutionary project that included Quebec's independence, proclaiming "no liberation of Quebec without the liberation of women, no liberation of women without the liberation of Quebec."20 While internal division would lead to the dissolution of the FLF in 1971, it was replaced by the Centre des Femmes, which also tied women's liberation to Quebec independence. ${ }^{21}$

Sensing an opportunity to incorporate a feminist movement apparently intent upon linking women's rights to Quebec's political independence, the Parti Québécois (PQ) made a number of overtures to attract feminists to the party. Following its election in 1976, it appointed Lise Payette, the popular television personality, as minister in charge of the status of women, increased the budget of the Conseil du statut de la femme, and appeared receptive to its report Pour les Québécoises: égalité et indépendance (1978) which put forward a number of recommendations designed to further women's equality. It also dropped the previous government's efforts to prosecute Henry Morgentaler for performing abortions, although it failed to defend abortion rights in its platform. ${ }^{22}$ In spite of such moves, the Centre des Femmes grew increasingly disillusioned with the PQ because the party appeared unable to overcome the temptation to equate national strength with large heterosexual families. ${ }^{23}$ The hope that the PQ would promote women's equality as vigorously as it did Quebec independence thus faded by the late 1970s, along with the enthusiasm of some women for nationalism.

Although many feminists had grown disillusioned with the PQ, the perception that the party was closely aligned with the feminist movement remained. A number of men wondered, for example, if the PQ's efforts to court feminists by linking the program of political liberation to women's emancipation might backfire and alienate those women who were not feminists. This view was reinforced in the final months of the 1980 referendum campaign when Lise Payette unintentionally denigrated women who were planning to vote against sovereignty-association and, in the process, halted the nationalist momentum. ${ }^{24}$ In the course of a public meeting organized to draw attention to stereotypical images of women found in the province's school textbooks, Payette implied that only un-liberated women, whom she labelled "Yvettes" after the submissive female character found in those texts, would vote against sovereignty-association. Accusing them of being afraid to vote "yes" and of being unwilling to assert their independence as women, she then lumped federalist Francophone women in with the province's Anglophones, who were planning to vote en masse against sovereignty-association, suggesting that they would share some of the blame should the referendum fail. ${ }^{25}$

Payette could not have expected the public uproar that followed. Many 
women objected to her suggestion that their allegiance to Canada somehow indicated that they were un-liberated. When 15000 women filled the Montreal Forum to protest her comments, many nationalist leaders were reminded of women's political influence and realized that women might tip the balance against them on voting day. In a stinging editorial in the nationalist Le Devoir, Lise Bissonnette accused Payette of treating women like "idiots," and of setting them up to become the scapegoats in the event of a referendum defeat. ${ }^{26}$ Even though most of the speakers at the Forum that night were well-known feminists, the rally was widely interpreted as an anti-feminist response from women who resented the manner in which the PQ had supposedly associated itself with militant women. As a result, a number of people within the PQ concluded that their efforts to court a minority of feminists had simply alienated the majority of women and cost them a referendum victory. ${ }^{27}$

This perception turned some men decisively against the feminist movement following the referendum. Lise Payette was not encouraged to seek reelection, while the PQ distanced itself from her type of feminism and pursued an agenda that promoted motherhood and the nuclear family by offering financial incentives for women to produce more than two children. ${ }^{28}$ A number of men also grew impatient with the suggestion that Quebec women were, or could be, oppressed in the ways that some feminists had described. The sociologist Jacques Grand'Maison, for example, denied that French-speaking Quebec men were in any position to dominate women because they were themselves colonized by English Canadians and thus incapable of wielding any real power over anyone. Men were the ones who have always been humiliated in the workplace, he noted, and who have been marginalized within the home. Men, he wrote, had become so feminized that they had been incapable of giving themselves political independence, suggesting, "nous avons été plutôt le sex honteux."29

At the same time, some nationalists could not hide their disappointment with the public for voting against independence and wondered if the result somehow reflected the state of Quebec manhood. The influential critic Jean Larose, for one, suggested that the loss exhibited Quebecers' "hystericized inability to "choose." ${ }^{\prime 30}$ In voting against independence, he claimed, men had forsaken their manhood, squandering their best opportunity to assert their "maturité phallo-nationale." ${ }^{31}$ The journalist Jean-Pierre Bonhomme agreed, arguing that the defeat had derailed men's passage into manhood and condemned them to remain in a perpetual state of adolescence. This collective state of arrested development, he suggested, explained the prevalence of "macho" men in the province who had become bad fathers and poor role models for their sons. ${ }^{32}$ These sons would grow up feeling betrayed by their fathers, who had failed to deliver on the promise of liberation..$^{33}$

Still others suggested that men had grown "soft" and dispirited, and had 
allowed women to dominate their lives ${ }^{34}$ According to Pierre de Bellefeuille, "notre mentalité de colonisé continue de faire obstacle. Car l'ennemi est en nous. Il n'est ni anglais, ni néo-québécois. Il s'appelle indécision. Il s'appelle mollesse. Il s'appelle économisme. ${ }^{135}$ Because women had quietly, and sometimes not so quietly, consolidated their presence in the public sphere as well as in the workforce, some men wondered if feminists had not created a culture in which it became acceptable to denigrate men. As the journalist Mathieu-Robert Sauvé recently pointed out, "alors que nos regards étaient tournés vers le mouvement féministe, un nouveau stéréotype a vu le jour au Québec: celui de l'homme misérable, malheureux, autodestructeur. S'il est père, c'est un homme absent, irresponsable, incapable d'émotions. C'est l'homme accablé d'une affliction permanente." ${ }^{36}$

By turning against women in this manner, French-speaking Quebecers tapped into a long history of blaming women for the challenges arising from economic dislocation and political failures. ${ }^{37}$ On occasion these frustrations translated into outright misogyny. Reggie Chartrand, a former boxer who was active in the early independence movement, provides one particularly virulent example of this emerging backlash against women. Chartrand was an everpresent figure at the violent demonstrations of the $1960 \mathrm{~s}$, and the founder of the Chevaliers de l'indépendance, a group established to promote Quebec independence. He had always dismissed women's demands for equality, describing them as either misguided or distractions to the larger cause of Quebec independence. During the early 1970s he suggested that women needed (and wanted) to be dominated by strong men, but he also expected women to fight alongside their men to secure Quebec independence. ${ }^{38}$ Yet following the defeat of the referendum in 1980, and no longer in the mood to court women's support for the cause, Chartrand unleashed his full anger at those women who had been, in his view, corrupted by feminism. In Dieu est un homme parce qu'il est bon et fort (1984) he described feminists as murderers for their defence of abortion rights, and ridiculed their calls for equality. But he was most upset that men had allowed these women to "emasculate" and "castrate" them, and that they had become so weak and dominated by them that they were unable to fulfil their dream of political independence. ${ }^{39}$

The defeat of the referendum turned out to be a significant moment in the lives of many men because it brought to an abrupt end the discipline and order that the nationalist movement had provided for them. ${ }^{40}$ Exhausted by the struggle of the preceding two decades and deprived of the focus that it brought, many men turned their attention to other aspects of their lives, only to realize that Quebec society had changed profoundly during the time that they had been focussed on the national question. The result of the referendum, combined with disillusion with the apparent weakness of the Quebec man, and the occasional outbursts against women, led some writers to suggest that there existed a crisis 
of manhood in the province. Books appeared purporting to explain men's supposed feelings of powerlessness in a society that they no longer recognized. While resentment toward women can hardly be said to have begun in the $1980 \mathrm{~s}$, the sociologist Germain Dulac did trace this particular strain of disaffection to the early 1970s, when a number of support groups for divorced men appeared in the province for those men feeling increasingly besieged in a world supposedly transformed by a feminist agenda. Dulac, one of the leading figures in the scholarly effort to write about masculinity in the 1980s and 1990s, suggests that men have been hit particularly hard in recent years because they had never developed the necessary skills to deal with the social transformations taking place around them. With the steady increase in divorce rates, for example, men have been left to cope with the emotional fallout within a culture that valorizes strength and emotional reserve. Having never learned to express their feelings, he suggests, men have become trapped by social expectations of idealized manhood. ${ }^{41}$

The idea that men were dealing silently with the bewildering changes taking place around them characterized much of the literature dealing with masculinity during these years. Marc Chabot, another early interpreter of this supposed crisis of masculinity, suggested that men have been unable to adapt to their new surroundings because they are products of an oppressive patriarchal and sexist regime that has denied them access to their own feelings and emotions. ${ }^{42}$ In L'homme désemparé (1988), the social worker and writer Michel Dorais noted that men have become disoriented in a world reshaped by reproductive technology, divorce, and the disruption of traditional gender roles. He wrote, "leur [men's] vie affective, sexuelle et familiale connaît des mutations significatives alors que l'identité, les rapports amoureux et la parentalité ne suivent déjà plus les même règles." ${ }^{\text {"3 }}$

The psychoanalyst Guy Corneau, founder of Réseau Hommes Québec, also emerged as an important voice for men who were feeling adrift. In his best-selling book Absent Fathers, Lost Sons (1991), Corneau, who has been called the "father of the men's movement" in Quebec, argued that there exists a "fragility of masculine identity" because fathers failed to teach their sons what it means to be men, thereby leaving them vulnerable to the effeminizing influence of their mothers. ${ }^{44}$ Corneau suggested that men can reverse their slide into effeminacy by becoming reacquainted with their more aggressive natures and rediscovering the "primitive man who slumbers in the unconscious." 45 He encouraged men to develop friendships with other men, claiming, "too many men live cut off and isolated from the male community."

In recent years, some sociologists have gone one step further, suggesting that these emotional traumas are putting men's health-and even their livesat risk. Germain Dulac, for example, points out that men are far less likely than women to visit their doctors or to go to the hospital when they are sick because 
they adhere to a code of masculinity that teaches them to ignore or manage their pain. At the same time, he warns, many social and health care workers are women, and these women have not been trained to recognize that men need as much help as women. As a result, most men are left without the support that they require. ${ }^{47}$

Michel Dorais has investigated the links between this code of masculinity and Quebec's high suicide rate. Focusing on young gay men in Quebec, he concludes that these men often turn to suicide in order to escape a rigidly heterosexual world that does not permit deviance from a macho standard of manhood. ${ }^{48}$ The sociologists Catherine Krull and Frank Trovato, meanwhile, have linked the high suicide rate in the general population to the province's modernization since the Quiet Revolution. The erosion of the traditional family since the 1960 s along with the declining influence of the Church, they suggest, have left men rudderless in a world without an adequate support network. This loss of collective support, they argue, partly explains the high suicide rate among men. While women have seen their roles in society expand, men have seen theirs diminish. In other words, "modernization in Quebec has been more detrimental to men than to women."

While much of this anxiety about manhood is evident in the rest of the country, there remains a sense that the problem is more acute in Quebec. In Échecs et mâles (2005) Mathieu-Robert Sauvé argues that French-speaking Quebec men in particular are suffering from a crisis of masculinity because they have been subjected to a string of political defeats and lack strong male role models. Quebec history, he writes, is filled with defeat, from the Conquest to the referendums on sovereignty. As a result, "les hommes voient leurs pères comme de vieux débris. Notre dramaturgie est envahie par des géniteurs bedonnants, alcooliques, dépressif et castrateurs." ${ }^{50}$ There are very few places, moreover, where boys can turn for positive male role models. He laments, "non seulement les écoles sont-elles le lieu des femmes, mais les modèles masculins positifs auxquels les jeunes pourraient s'identifier sont rares dans la collectivité." Al And in spite of his repeated claims to support the goals of the feminist movement, Sauvé warns that men are now dominated by women, suggesting, "nous avons plutôt le père petit. C'est en général un homme pusillanime, timoré, quasi muet, dominé par sa femme comme son père l'a été par la sienne et comme son fils l'est par sa blonde." 52

The Quebec literature on masculinity, then, links the supposed crisis of masculinity to the political failures of certain nationalists and to the perceived gains women have made over the last three decades. But it is also taking shape against the backdrop of the men's movement in the United States, which emerged in response to some men's perception that they were losing ground to women..$^{53}$ While the leaders of the American men's movement usually denied that they were driven by an anti-feminist agenda, their words often revealed a 
deeper ambivalence toward women. The American poet Robert Bly, for example, perhaps the most influential figure in the men's movement, appears to blame women for men's supposed troubles, suggesting, "there's a disease going around, and women have been spreading it. Starting in the " 60 s women have really invaded men's areas and treated them like boys." ${ }^{\circ 4}$ As he complains in his book Iron John: A Book About Men (1990), the result has been a generation of "soft males" who have lost touch with their inner warrior and become disconnected from their wild nature. These men need to break free from their mother's influence, Bly argues, and to make contact with the "Wild Man," a "large, primitive being covered with hair down to his feet" that "is lying at the bottom of his psyche." ment in the 1980s, Bly led a number of retreats into the wilderness for men who wished to rediscover their repressed manhood. Such exposure to nature, he argued, would help men overcome their feminized upbringing in the home.

If some people were at first bemused by this movement, it would not be long before this men's revolt attracted serious attention. By the end of the decade the feminist journalist Susan Faludi, who had earlier sounded the alarm about what she called the "war against American women," turned her attention to the men's movement and uncovered a profound "crisis" of masculinity. In her book Stiffed: The Betrayal of the American Man (1999), Faludi suggests that the post-war generation of men, the so-called "greatest generation," had failed to deliver on a set of promises that they had made to their sons. She writes, "the boy who had been told he was going to be the master of the universe and all that was in it found himself master of nothing," and argues that a "social pact between the nation's men and its institutions was collapsing, most prominently but not exclusively within the institution of work." Men appear to have "lost their compass in the world," she claims, and with it the hope that they would fulfil the promise of the post-war years. These men, she argues, grew up to discover that they were "dominated," and "done in by the world," and had become the victims of the very patriarchal society that they had inherited from their fathers and within which they were accused of wielding misogynistic power. ${ }^{56}$

Until recently, the suggestion that men needed to be studied more might have appeared absurd - - or offensive - to those historians who could have pointed out that the entire historical project has been dominated by men for quite some time..$^{57}$ Early efforts to "recover" men's lives were thus treated with some suspicion, as was the tendency of some men's historians to borrow liberally from women's history. Many historians of masculinity, for example, adopted the separate spheres paradigm as a conceptual framework at the very time when many women's historians were questioning its utility. ${ }^{58}$ Early work on manhood tended to focus on fraternal groups, male friendships, and male space, making little effort to produce what could be called gender history. ${ }^{59}$ 
The speed with which masculinity studies has emerged as a field has also prompted some observers to wonder if it might simply re-centre men in the historical narrative by re-marginalizing women's history before it has achieved many of its objectives. ${ }^{60}$ The fact that the historical profession has appeared much more willing to embrace the new history of masculinity than it had been to accept women's studies in the past has only fuelled these suspicions. This professional recognition, moreover, has relieved historians of masculinity from the need to defend and justify the legitimacy of their work, which women's historians had been forced to do, enabling them to pursue their research and to catapult the field to the prominent place it now enjoys. One might also wonder if history departments, which remain largely under the control of men, have embraced masculinity studies as a convenient means of fulfilling professional commitments to gender studies without having to devote as many resources to women's history.

A number of historians have also expressed concern that the study of masculinity has contributed to the drift away from material history by focussing on the constructed and contingent nature of manhood and womanhood, prompting some to complain that gender history threatens to divert attention away from the actual experiences of men and women in the past. The concern that this new history sidesteps the real experiences of men and women in favour of representations of those experiences raises fears that such a shift in focus threatens to sidestep the realities of women's oppression. ${ }^{61}$ The historian Joy Parr observes that "feminists have worried that poststructuralism might perform 'a vanishing trick on questions of agency and responsibility' in sexual politics, so fragmenting masculine power that it becomes elusive to strategy and apparently politically benign." Joan Sangster, too, warns, "there is a danger that historical work on masculinity will repeat one stream of the contemporary men's movement, which urges men to 'reclaim their tears' but ignores men's power and women's oppression." By focussing on the "nicer side of masculinity," she writes, masculinity studies risk sidestepping "the unpleasant questions of power, domination and patriarchy." ${ }^{\prime 63}$ The concern, according to Bryce Traister, is that masculinity studies will produce "a disciplinary field in which all genders and sexualities are equally constructed, even if they do not share equal political and social power." ${ }^{4}$ Indeed, one of the major challenges of the new history of masculinity is to reconcile the insights about the contingent nature of male identity with the very real power that men possess and exercise.

While it is tempting to dismiss much of the work on masculinity as a ploy to recast men as the anguished, emotionally-stunted, and helpless victims of a world of their own making - one over which they now claim to have little control-efforts to illustrate the contingent nature of manhood need not detract from the ongoing feminist historical project. One of the primary objectives of masculinity studies is to remove manhood from its biological moorings by 
exposing it as a historically contingent and constructed identity. It was the invisibility of male power, after all, and the assumed naturalness of men's privileged position within society's patriarchal structure that contributed to men's authority. So by turning our attention to the formerly unexamined workings of men's gendered identities we can expose the ways in which patriarchy has operated in the past and, in the process, make it easier to overcome gender inequality in our own time. In this sense, then, it is true that men have rarely been studied "as men," and doing so may allow us to further understand the patriarchal structures that continue to oppress women.

Literary critics in Quebec have been among the first to treat men as gendered historical actors in order to explore the ways that certain discourses about masculinity serve political agendas that silence women's voices ${ }^{65}$ Journalists and sociologists, on the other hand, tend to focus on the challenges men encounter as they adjust to a society that is supposedly being transformed by feminism and that is characterized by political failure. Quebec historians, for their part, are only beginning to investigate masculinity. So far they have chronicled the development of men's gendered identities in a manner that resembles the recovery effort that characterized the early stages of masculinity studies in the rest of North America. They have appeared reluctant to investigate the ways that men's gendered identities informed their political actions and perpetuated the oppression of women. Instead, they have tended to focus on the ways that men have suffered under the weight of patriarchal expectations.

To be sure, Quebec historians have been investigating gender in the province for some time. Some, like Susan Mann Trofimenkoff, in an article on Henri Bourassa thirty years ago, and Allan Greer, in his work on the Rebellions in Lower Canada, have written about masculinity. ${ }^{66}$ But masculinity studies in history can truly be said to have arrived in the province in 2004 with the publication of a special issue on masculinity and femininity of Revue d'histoire de l'Amérique française. While the appearance of this issue signals that historians are finally ready to take on the question of masculinity, the articles suggest that this first step remains tentative. In his introductory essay, for example, Ollivier Hubert treats gender history as a somewhat foreign idea, describing it as an "American phenomenon" that is grounded in "Anglo-Saxon" research on the differences between sex and gender. ${ }^{67}$ Moreover, Hubert concedes that the articles in this issue deal only marginally with what could be termed gender history. Indeed, they appear more intent upon recovering men's previously unexplored lives rather than exploring gender history.

Many of the articles in that special issue illustrate the ways in which particular ideas about masculinity hurt both women and men, and uncover the supposed limits of patriarchal power. Cynthia Fish, for example, explores the decline of paternal power during the early twentieth century. Looking at court cases dealing with marital separation, Fish notes that women became much 
more likely to win custody of their children by the end of the nineteenth century because judges tended to assume that women were more nurturing than men. So while the Civil Code stipulated that men had complete control over their children, the evidence suggests that men's parental rights were eroding by the twentieth century. ${ }^{68}$ In another article, Vincent Duhaime suggests that historians have downplayed the important role that men have played in the home and in the lives of their children during the middle of the twentieth century. $\mathrm{He}$ points out that men were encouraged to find a place in the home, and that the evidence suggests that men were much more important in the running of the household and in raising their children than has been assumed. ${ }^{69}$ Both writers shy away from the potentially liberal thread of masculinity studies by offering a critique of patriarchy primarily on the basis of its harmful effects on men, rather than women. While Duhaime attempts to recover an overlooked chapter in men's lives, Fish highlights the ways in which perceptions of masculinity could have a negative impact on men and even limit their access to their children. In many ways, then, these articles resemble some of the early efforts at recovery in the North American literature.

If this effort to recover men's previously unexamined lives is perhaps to be expected of a new field in search of its subject, it also points to a larger difficulty that historians of masculinity in Quebec face. One reason that the historical study of masculinity has been slow to appear in the province, and that the first forays into that field have tended to be recovery efforts, is that the study of masculinity threatens to unravel the narrative of Quebec's evolution as a modern and liberal society. And historians, it turns out, have played an important role in constructing the state as a positive force in this modernization narrative.

Until the 1970s, most scholars had focussed on those aspects of the Quebec experience that marked the province as different from the rest of Canada. For some historians, those usually associated with the Montreal school of historical writing, the Conquest loomed large as the moment in the Quebec experience that explains French-speaking Quebecers' failure to modernize until the middle of the twentieth century. Other historians who made up the Laval school of historical writing downplayed the importance of the Conquest, arguing instead that the province failed to modernize at the same pace as the rest of the country because French-speaking Quebecers actively resisted change in an effort to preserve traditional agrarian values. While both sides arrived at different conclusions about who and what was to blame for Quebec's apparent inability to compete with the rest of the country, neither side challenged the idea that the province stood outside the normal development of the continent and resisted modernization until the twentieth century. But by the late 1970s, a new generation of historians began emphasizing those aspects of Quebec's past that made it appear more like the other provinces. The assumption that the province developed in ways that were different from the North American norm, accord- 
ing to Paul-André Linteau, one of the leading proponents of this new history, "was not responding to our concerns. Accordingly, we set off to explore the various factors that led to the emergence of an industrial, capitalist society in Quebec by the middle of the nineteenth century." 70

In 1979, Linteau, along with René Durocher and Jean-Claude Robert, produced Histoire du Québec contemporain, the first history of post-Confederation Quebec. ${ }^{71}$ In the book, they downplayed linguistic, ethnic, and religious conflict in the past- that is, any angle that could mark Quebec as different from the rest of Canada. By focusing on larger trends such as urbanization and industrialization, they made the province appear more urban and industrial, that is to say more liberal or "normal," than was previously assumed. Other historians were quick to embrace this new narrative. In Progrès, harmonie, liberté (1988), for example, Fernande Roy highlights Quebec's liberal tradition by downplaying the degree of clerical authoritarianism in the province. Gilles Bourque, Jules Duchastel, and Jacques Beauchemin, in La société libérale duplessiste (1994), also challenge assumptions that Quebec was "backward" prior to 1960 by uncovering liberal currents during the Maurice Duplessis era. ${ }^{72}$

This new history served an important function in a society that appeared eager to erase the increasingly embarrassing perception that Quebec's past was backward or illiberal. According to Gérard Bouchard, it also positioned Quebec "in the mainstream of developments both in North America and across the western world. From this perspective, Quebec was as industrial, as capitalistic, as liberal, as developed, in short as modern as other societies." ${ }^{\text {"73 }}$ What is interesting about this work is that efforts to downplay the importance of the Quiet Revolution as a turning point did not take away from the liberalism of the 1960s. Rather, it simply projected that liberalism further into the past.

At first glance, and considering the lengths to which historians have gone to integrate Quebec's experience into the North American mainstream, the reluctance to embrace the recent development of masculinity studies might appear surprising. In fact, it is precisely this determination to emphasize Quebec's liberal past that has worked against the development of masculinity studies in the province. The manner in which masculinity studies has evolved as a field in the rest of North America, it turns out, poses a serious challenge to the effort to integrate Quebec's history into continental trends, and thus partly explains its limited appeal in the province. That is to say, many Quebec historians have avoided gender history in general and masculinity studies in particular precisely because they have been reluctant to adopt the methodological approaches or engage in the debates that are at the heart of masculinity studies elsewhere.

Much of the effort to integrate Quebec history into the mainstream of North American historical development has been based on empirical research intended to "prove" that Quebec has progressed at the same pace that other western 
societies have. Historians turn to statistics pointing to a declining birthrate in the province, for example, to challenge the stereotype that French-speaking Quebecers continued to have large families well into the twentieth century. As well, they uncover evidence that French-speaking Quebecers participated in commerce and business in much the same ways that English Canadians had. Their aim is to erase any reminders that Quebec was "backward," or had failed to progress along with the rest of the country. Historians who insist on depicting Quebec history as different are criticized for reinforcing old stereotypes about the province's backwardness, and sometimes accused of professional mischief for politicizing their work, which is a significant rebuke in a profession that has come to define itself by its scientific approach to the past. ${ }^{74}$

Since the "normalization" of Quebec's past was secured largely through empirical research that became popular in the province beginning in the $1960 \mathrm{~s}$, any work that emphasises the discourses of the period at the expense of "scientific" evidence threatens to highlight Quebec's distinctiveness once again, in the process unravelling a generation of social scientists' efforts to rewrite Quebec history as a narrative of progress toward a modern and secular, that is to say liberal, state. ${ }^{75}$ The new study of masculinity, which is part of the drift within the historical profession away from the material past and toward the study of discourse, threatens to shine a light on precisely those illiberal discourses that supposedly marked Quebec society as different. ${ }^{76}$

Those historians, then, who continue to associate the enhanced role of the provincial state since the 1960 s with the liberation of the Quebec people, would be reluctant to pursue masculinity studies. According to Éric Bédard, Quebec historians are also reluctant to pursue the history of conservatism in the province because it would threaten this narrative of progress. ${ }^{77}$ Similarly, many Quebec historians perceive gender history, with its implicit goal of exposing the ways in which the patriarchal state oppresses women, as a threat to the very state apparatus that is alleged to be at the centre of Quebec identity. The historian Micheline Dumont points out that historical studies that highlight women's subjugation or their exclusion from the state, for example, are not priorities for historians seeking to uphold the idea that Quebec was, and is, a liberal society. In addition to undermining efforts to highlight liberal and progressive threads in the Quebec experience, such work would challenge the assumption that the modern state serves as an instrument to emancipate all of its citizens. At the same time, Dumont argues, "Centrés compulsivement sur la nouvelle identité québécoise, les historiens québécois auraient les plus grandes difficultés à integrer les perspectives théoriques qui remettent en question les pré-supposés masculins de l'identité québécoise." ${ }^{.7}$ In the same way that Jean Charest's efforts to downsize the state are described as "foreign" to Quebec sensibilities, so too are efforts to portray the state as a heteromasculinist or misogynistic entity seen to betray the spirit of the Quiet Revolution. 
$110 \quad$ Vacante

While some writers have expressed concern that gender history might undermine the narrative of progress that has emerged since the Quiet Revolution, others have argued that the progress being made was illusory. Beginning in the $1970 \mathrm{~s}$, a number of writers pointed out that the Quiet Revolution had done little to address the inequities of the capitalist system that had for years hurt the province's working classes. They argued that the various reforms of the 1960s had simply integrated the province further into the oppressive mould of North American capitalism, making it more difficult to achieve the social justice that many people had hoped would be achieved with the Quiet Revolution. ${ }^{79}$ As disappointment with the direction of reform increased in the 1970 s, a growing number of intellectuals and labour leaders criticised the PQ for its apparent pursuit of a form of bourgeois nationalism that offered little to the working classes..$^{80}$ The popularity in the 1970s of such Marxist interpretations of Quebec's modernization, along with the anti-colonial movement of the 1960s that they built upon, represented considerable obstacles to the development of a strong feminist movement in Quebec. Women who sought to highlight sexual inequality encountered resistance from those people who remained focused on the class struggle and on the national question. ${ }^{81}$ For those people who fought for class realignment or national emancipation, then, the Quiet Revolution offered only limited progress. And because their objective of meaningful progress remains unfulfilled, issues such as feminism, and now masculinity studies, can only be regarded as divisive and as distractions on the road to reform. ${ }^{82}$

Consequently those historians who remain committed to the idea of an activist Quebec state that serves as an instrument to promote economic prosperity and to prop up a fragile identity are confronted with a dilemma when it comes to writing about masculinity. The prospect that the study of masculinity could undermine the legitimacy of the state is less appealing in a province where a strong state remains central to the maintenance of Quebec's economic power and culture. There remains a tendency to avoid masculinity studies due to a concern that it might expose the illiberal and oppressive nature of a supposedly liberal state apparatus that so many people still value. At the same time, those writers seeking greater class equality and an end to the bourgeois nationalism espoused by the PQ may downplay the importance of gender inequality so long as the national question and the class struggle remain unresolved. Attachments to these ideological positions, combined with the fact that historians in Quebec are only just beginning to define the parameters of the field, and in addition to a lingering attachment to empiricism within the profession, have produced a version of masculinity studies with only a limited ability to explore gender relations in the province.

Quebec historians have, for the moment, embraced a less useful version of masculinity studies that simply re-centres white, heterosexual men in the histor- 
ical narrative as well as in the public mind. If a more progressive thread of masculinity studies is to take hold in the province, historians will need to approach the state less as a benevolent vehicle for Quebec's empowerment and more as the exclusionary and misogynistic instrument that it really is. It remains to be seen if the initial work on the subject will lead to a more critical assessment of masculinity in Quebec's past or if it will continue to emphasize the ways that men have been victimized by the same patriarchal culture that feminist historians have identified as harmful to women. What is certain is that the idea that Quebec nationalism is somehow defined by liberal values such as pluralism and tolerance is untenable so long as historians continue to ignore evidence that it has served as an instrument to prop up the illiberal objective of securing men's domination over women.

\section{Notes}

1. Ian McKay, Rebels, Reds, Radicals: Rethinking Canada's Left History (Toronto: Between the Lines, 2005), 191-92; Joseph H. Carens, "Liberalism, Justice, and Political Community: Theoretical Perspectives on Quebec's Liberal Nationalism," in Is Quebec Nationalism Just? Perspectives from Anglophone Canada (Montreal and Kingston: McGill-Queen's University Press, 1995), 3; Reg Whitaker, "Quebec and the Canadian Question," in A Sovereign Idea: Essays on Canada as a Democratic Community (Montreal and Kingston: McGill-Queen's University Press, 1992), 288-89.

2. Kenneth McRoberts, Misconceiving Canada: The Struggle for National Unity (Toronto: Oxford University Press, 1997), 33; Michel Sarra-Bournet, "Nationalisme et question nationale au Québec," in Les nationalismes au Québec du XIXe au XXIe siècle, eds. Michel Sarra-Bournet and Jocelyn Saint-Pierre (Quebec: Presses de l'Université Laval, 2001), 336. See also Christian Leuprecht, "The Liberal Contradictions of Québec Nationalism," Canadian Review of Studies in Nationalism 29, no., 1-2 (2002): 15.

3. Sarra-Bournet, "Nationalisme et question nationale au Québec," 342.

4. Gérard Bouchard, "Ouvrir le cercle de la nation: Activer la cohésion sociale. Réflexions sur le Québec et la diversité," in Sarra-Bournet and Saint-Pierre, Les nationalismes au Québec, 327.

5. La Presse, 28 October 1995.

6. On the Quebec labour movement's support for sovereignty, see Ralph Güntzel, "'Rapprocher les lieux du pouvoir': The Québec Labour Movement and Québec Sovereigntism, 1960-2000," Labour/Le Travail 46 (Fall 2000): 387, 391.

7. Gérald Larose, "L'emplacement du CHUM: une décision essentiellement politique," Le Devoir, 4 February 2005. Paul Wells notes that this is part of a growing trend in the province, in "John By Any Other Name," Maclean's, 28 March 2005, 64. See also René Lewandowski, "La dame de fer," L'Actualité, 1 March 2004, 25-30; Isabelle Grégoire, "Y a-t-il une droite, au Québec?" L'Actualité, 1 April 2005, 20-28. The fact that the federal Conservative breakthrough in Quebec in the 2006 election was so unexpected shows just how ingrained the idea that conservatism is foreign to Quebec had become. This perception remains despite the presence of the right-of-centre Mario Dumont and his Action Démocratique du Québec. 
8. Mathieu-Robert Sauvé, Échecs et mâles: les modèles masculins au Québec, de Marquis de Montcalm à Jacques Parizeau (Montreal: Éditions des Intouchables, 2005), 77.

9. Pierre Nepveu, L'écologie du réel: Mort et naissance de la littérature Québécoise contemporaine. Essais (Montreal: Boréal, 1988), 72.

10. Diane Lamoureux, "Nationalism and Feminism in Quebec: An Impossible Attraction," in Feminism and Political Economy: Women's Work, Women's Struggles, eds. Heather Jon Maroney and Meg Luxton (Toronto: Methuen, 1987), 51.

11. Victor Barbeau, Pour nous grandir: Essai d'explication des misères de notre temps (Montreal: Imprimé au “Devoir," 1937), 51, 153; Barbeau, Mesure de notre taille (Montreal: Imprimé au Devoir, 1936), 16. See also Louise Bienvenue and Christine Hudon, "'Pour devenir homme, tu transgresseras...' Quelques enjeux de la socialisation masculine dans les collèges classiques québécois (1880-1939)," Canadian Historical Review 86, no. 3 (September 2005): 490-91.

12. On the evolving ideal of Quebec men from rugged outdoorsmen to industrial worker and ultimately to entrepreneurial hero, see Jocelyn Létourneau, "La nouvelle figure identitaire du Québécois: Essai sur la dimension symbolique d'un consensus social en voie d'émergence," British Journal of Canadian Studies 6, no. 1 (1991): 17-19.

13. McKay, Rebels, Reds, Radicals, 185-88; Diane Lamoureux, L'amère patrie: Feminisme et nationalisme dans le Québec contemporain (Montreal: Les Éditions du remue-ménage, 2001), 118.

14. Patricia Smart, Writing in the Father's House: The Emergence of the Feminine in the Quebec Literary Tradition (Toronto: University of Toronto Press, 1991), 190. See also Michael Klementowicz, "Jacques Godbout's Salut Galarneau!: Identity and Violence Towards Women," Québec Studies 14 (Spring/Summer 1992): 83-91; Gordon Sheppard, "Violence and the French-Canadian Male," in Canada: A Guide to the Peaceable Kingdom, ed. William Kilbourn (Toronto: Macmillan of Canada, 1970), 193. 15. Katherine A. Roberts, "Making Women Pay: Revolution, Violence, Decolonizing Quebec in Hubert Aquin's Trou de mémoire," Québec Studies 30 (Fall/Winter 2000): 20. 16. Mary Jean Green, "Jacques Godbout and the Quebec Writer: Engendering the National Text," Quebec Studies 30 (Fall/Winter 2000), 8. See also Francine Bordeleau, "L'écrit du masculin," Lettres Québécoises 100 (Winter 2000): 14-18; Richard Duchaine, "De quelques occasions de bonheur sur le Plateau Mont-Royal," Voix et Images 18, no. 1 (Fall 1992): 39-51; Jean-Pierre Lapointe, "Narcisse travesti: L'altérité des sexes chez trois romanciers québécois contemporains," Voix et Images 18, no. 1 (Fall 1992): 11-25.

17. On the connections between Quebec nationalism and sexuality see Robert Schwartzwald, "'Symbolic' Homosexuality, 'False Feminine,' and the Problematics of Identity in Québec," in Fear of a Queer Planet: Queer Politics and Social Theory, ed. Michael Warner (Minneapolis: University of Minnesota Press, 1993); Elspeth Probyn, "Bloody Metaphors and Other Allegories of the Ordinary," in Between Woman and Nation: Nationalism, Transnational Feminism, and the State, ed. Caren Kaplan, Norma Alarcón, and Minoo Moallem, 47-62 (Durham, NC: Duke University Press, 1999); Probyn, "Love in a Cold Climate": Queer Belongings in Quebec (Montreal: Research Group on Cultural Citizenship, 1994); Elaine Pigeon, "Hosanna! Michel Tremblay's Queering of National Identity," in In a Queer Country: Gay and Lesbian Studies in the 
Canadian Context, ed. Terry Goldie, 27-40 (Vancouver: Arsenal Pulp Press, 2002); Peter Dickinson, Here is Queer: Nationalisms, Sexualities, and the Literatures of Canada (Toronto: University of Toronto Press, 1999), 101-30.

18. Robert Schwartzwald, "Fear of Federasty: Québec's Inverted Fictions," in Comparative American Identities: Race, Sex and Nationality in the Modern Text, ed. Hortense J. Spillers (New York: Routledge, 1991), 179.

19. Lamoureux, "Nationalism and Feminism in Quebec," 51.

20. Sean Mills, "Québécoises Deboutte! Le front de libération des femmes du Québec, le centre des femmes et le nationalisme," Mens: Revue d'histoire intellectuelle de l'Amérique française 4, no. 2 (Spring 2004), 191.

21. Ibid., 188-95.

22. Micheline Dumont, "Women of Quebec and the Contemporary Constitutional Issue," in Gender and Politics in Contemporary Canada, ed. François-Pierre Gingras (Toronto: Oxford University Press, 1995), 156; Diane Lamoureux, Fragments et collages: essai sur le féminisme québécois des années 70 (Montreal: Les Éditions du remue-ménage, 1986), 65; Lamoureux, "Nationalism and Feminism in Quebec," 60-61. 23. Mills, "Québécoises Deboutte!" 198-202; Lamoureux, "Nationalism and Feminism in Quebec," 55-57, 60-61; Roberta Hamilton, "Pro-Natalism, Feminism, and Nationalism," in Gingras, Gender and Politics in Contemporary Canada, 143-44, 146. 24. Stéphanie Godin, "Les Yvettes comme l'expression d'un féminisme fédéraliste au Québec," Mens: Revue d'histoire intellectuelle de l'Amérique française 5, no. 1 (Fall 2004): 73-117; Susan Mann Trofimenkoff, The Dream of Nation: A Social and Intellectual History of Quebec (Toronto: Macmillan, 1982), 330-31.

25. Le Devoir, 10 March 1980.

26. Le Devoir, 11 March 1980; 12 March 1980.

27. Lysiane Gagnon notes that in the days after the referendum some people made Payette the "scapegoat" for the loss, in Vivre avec les hommes: un nouveau partage (Montreal: Québec/Amérique, 1983), 178. Lise Payette acknowledged that some people within the party blamed her remarks for the loss in Des femmes d'honneur, Vol. 3, Une vie engagée, 1976-2000 (Montreal: Éditions Libre Expression, 1999), 89-90. See also Gagnon, Chroniques politiques (Montreal: Boréal Express, 1985), 17, 63; Lamoureux, L'amère patrie, 152.

28. Hamilton, "Pro-natalism, Feminism, and Nationalism," 146; Lamoureux, "Nationalisme et féminisme: Impasse et coincidences," Possibles 8, no. 1 (1983): 57-58. 29. Jacques Grand'Maison, La révolution affective et l'homme d'ici (Montreal: Leméac, 1982), 31, 34-35. See also Rock Côté, Manifeste d'un salaud (Montreal: Éditions du Portique, 1990).

30. Schwartzwald, "Fear of Federasty," 190.

31. Jean Larose, La petite noirceur (Montreal: Boréal, 1987), 175-76; Schwartzwald, "'Symbolic' Homosexuality," 266-67.

32. Jean-Pierre Bonhomme, "Quelques rêves à ranimer," in Le syndrome postréférendaire, ed. Bonhomme, et al. (Montreal: Stanké, 1989), 132.

33. Pierre Mignault, "Notre sainte frousse nationale," in Bonhomme, Le syndrome postréférendaire, 39-40; Anouk Bélanger, "The Last Game? Hockey and the Experience of Masculinity in Quebec," in Sport and Gender in Canada, eds. Philip White and Kevin Young (Don Mills, ON: Oxford University Press, 1999), 298-303. 


\section{$114 \quad$ Vacante}

34. See Patricia Smart, "When 'Next Episodes' Are No Longer an Option: Quebec Men's Writing in a Postfeminist, Postnationalist Age," Québec Studies 30 (Fall/Winter 2000): 30-31, 37 .

35. Pierre de Bellefeuille, L'ennemi intime (Montreal: L'Hexagone, 1992), 25.

36. Sauvé, Échecs et mâles, 72-73.

37. See Andreas Huyssen, "Mass Culture as Woman: Modernism's Other," in After the Great Divide: Modernism, Mass Culture, Postmodernism (Bloomington and Indiana: Indiana University Press, 1986), 52-53.

38. Reggie Chartrand, La dernière bataille (Montreal: Éditions Parti pris, 1972), 16061.

39. Reggie Chartrand, Dieu est un homme parce qu'il est bon et fort: La révolte d'un homme contre le féminisme (Montreal: Stanké, 1984), 20, 107, 158-59.

40. Lamoureux, "Nationalism and Feminism in Quebec," 63. On the post-referendum malaise, see Bonhomme, et al., Le syndrome postréférendaire; En collaboration, Québec: un pays incertain. Réflexions sur le Québec post-référendaire (Montreal: Québec/Amérique, 1980); Gagnon, Chroniques politiques, 67. For more on the "melancholy nationalists," see Jocelyn Maclure, Quebec Identity: The Challenge of Pluralism (Montreal and Kingston: McGill-Queen's University Press, 2003), 19-60.

41. Germain Dulac, Penser le masculin: Essai sur la trajectoire des militants de la condition masculine et paternelle (Quebec: Institut québécois de recherche sur la culture, 1994), 12, 25, 84; Dulac, "De la métamorphose au genre masculin," Recherches sociographiques 32, no. 3 (September-December 1991): 422; Dulac, "Masculinité et intimité," Sociologie et société 35, no. 2 (Fall 2003): 14-15, 28.

42. Marc Chabot, Des hommes et de l'intimité (Montreal: Éditions Saint-Martin, 1987). 43. Michel Dorais, L'homme désemparé. Les crises masculines: les comprendre pour s'en dépendre (Montreal: VLB Éditeur, 1988), 14. See also, Renée-B. Dandurand, Le mariage en question, essai sociographique (Quebec: Institut québécois de recherche sur la culture, 1988); Dulac, "De la métamorphose au genre masculin," 419; Dulac, Penser le masculin, 25.

44. Bélanger, "The Last Game?" 299.

45. Guy Corneau, Absent Fathers, Lost Sons: The Search for Masculine Identity (Boston: Shambhala, 1991), 3, 128-29.

46. Ibid., 172 .

47. Germain Dulac, Aider les hommes...aussi (Montreal: VLB Éditeur, 2001), 140-42.

48. Michel Dorais, with Simon L. Lajeunesse, Dead Boys Can't Dance: Sexual Orientation, Masculinity, and Suicide, trans. Pierre Tremblay (Montreal and Kingston: McGill-Queen's University Press, 2004).

49. Catherine Krull and Frank Trovato, "The Quiet Revolution and the Sex Differential in Quebec's Suicide Rates: 1931-1986," Social Forces 72, no. 4 (June 1994): 1121, $1142-43$.

50. Sauvé, Échecs et mâles, 18-19. Jean Larose, too, writes "Peut-être n'y-a-t-il nulle part ailleurs une société où la fonction de père soit aussi généralement méprisée, méconnue, oubliée, voire forclose," in La petite noirceur, 184.

51. Sauvé, Échecs et mâles, 303.

52. Ibid., 9.

53. Bryce Traister suggests that "heteromasculinity studies is the academic answer to 
the regressive politics of 'menz ideology' now proliferating in mainstream periodicals, radio, and television," in "Academic Viagra: The Rise of American Masculinity Studies," American Quarterly 52, no. 2 (June 2000): 278.

54. Quoted in Susan Faludi, Backlash: The Undeclared War Against American Women (New York: Anchor Books, 1992), 310. For an elaboration of this sentiment, see Paul Nathanson and Katherine K. Young, Spreading Misandry: The Teaching of Contempt for Men in Popular Culture (Montreal and Kingston: McGill-Queen's University Press, 2001).

55. Robert Bly, Iron John: A Book About Men (Reading, MA: Addison-Wesley, 1990), 2-3, 6, 18-19, 24-25, 180-82. See also Sam Keen, Fire in the Belly: On Being a Man (New York: Bantam, 1991); Michael Swalbe, Unlocking the Iron Cage: The Men's Movement, Gender Politics, and American Culture (New York: Oxford University Press, 1996). For historical antecedents to this movement see Gail Bederman, Manliness and Civilization: A Cultural History of Gender and Race in the United States, 18801917 (Chicago: University of Chicago Press, 1995), 77-120, 235-39.

56. Faludi, Stiffed: The Betrayal of the American Man (New York: William Morrow and Company, 1999), 9, 13, 30, 43.

57. Michael Kimmel, for example, opens his book on American manhood by stating, "American men have no history." See his Manhood in America: A Cultural History (New York: Free Press, 1996), 1.

58. Linda Kerber, "Separate Spheres, Female Worlds, Woman's Place: The Rhetoric of Women's History," Journal of American History 75, no. 1 (June 1988): 9-39.

59. See for example, Mark C. Carnes, Secret Ritual and Manhood in Victorian America (New Haven: Yale University Press, 1989). For critiques of this trend see Joy Parr, "Gender History and Historical Practice," Canadian Historical Review 76, no. 3 (September 1995): 369; Nancy F. Cott, "On Men's History and Women's History," in Meanings for Manhood: Constructions of Masculinity in Victorian America, eds. Mark C. Carnes and Clyde Griffen (Chicago: University of Chicago Press, 1990), 208.

60. This fear resembles similar concerns that gender history threatens to overshadow the gains made by women's historians. See Joan Sangster, "Beyond Dichotomies: ReAssessing Gender History and Women's History in Canada," Left History 3, no. 1 (Spring/Summer 1995): 109-21.

61. Franca Iacovetta and Linda Kealey, "Women's History, Gender History and Debating Dichotomies," Left History 3, no. 2/4, no. 1 (Fall 1995/Spring 1996): 227. 62 Parr, "Gender History and Historical Practice," 366; Traister, "Academic Viagra," 292.

63. Sangster, "Beyond Dichotomies," 117-18.

64. Traister, "Academic Viagra," 297.

65. See Québec Studies 30 (Fall/Winter 2000) and Voix et Images 18, no. 1 (Fall 1992) for special issues on questions of masculinity.

66. Susan Mann Trofimenkoff, "Henri Bourassa and 'The Woman Question,"' Journal of Canadian Studies 10, no. 4 (November 1975): 3-11; Allan Greer, "La république des hommes: les patriotes de 1837 face aux femmes," Revue d'histoire de l'Amérique française 44, no. 4 (Spring 1991): 507-28. See also Brian Young, "The Volunteer Militia in Lower Canada, 1837-50," in Power, Place and Identity: Historical Studies of Social and Legal Regulation in Quebec, eds. Tamara Myers, Kate Boyer, Mary Anne 
Poutanen and Steven Watt, 37-53 (Montreal: Montreal History Group, 1998); Young, The Politics of Codification: The Lower-Canadian Civil Code of 1866 (Montreal and Kingston: McGill-Queen's University Press, 1994), 140-56; Bélanger, "The Last Game?"; Jarrett Rudy, "Unmaking Manly Smokes: Church, State, Governance, and the First Anti-Smoking Campaigns in Montreal, 1892-1914," Journal of the Canadian Historical Association 12 (2001): 95-114; Suzanne Morton, “A Man's City: Montreal, Gambling and Male Space in the 1940s," in Myers, Boyer, Poutanen, Power, Place and Identity, 169-82; Morton, At Odds: Gambling and Canadians, 1919-1969 (Toronto: University of Toronto Press, 2003), 69-88.

67. Ollivier Hubert, "Féminin/masculin: l'histoire du genre'," Revue d'histoire de l'Amérique française 57, no. 4 (Spring 2004): 473, 478.

68. Cynthia Fish, "La puissance paternelle et les cas de garde d'enfants au Québec, 1866-1928," Revue d'histoire de l'Amérique française 57, no. 4 (Spring 2004): 509-33. 69. Vincent Duhaime "Les pères ont ici leur devoir": le discours du mouvement familial québécois et la construction de la paternité dans l'après-guerre, 1945-1960," Revue d'histoire de l'Amérique française 57, no. 4 (Spring 2004): 535-66. See also in that issue, Christine Hudon and Louise Bienvenue, "Entre franche camaraderie et amours socratiques. L'éspace trouble et ténu des amitiés masculines dans les collèges classiques (1870-1960)," 481-507; Isabelle Perrault, "Morale catholique et genre féminin: la séxualité dissertée dans les manuels de sexualité maritale au Québec, 1930-1960," 567-90; Karine Hébert, "Carabines, poutchinettes co-eds ou freshettes sont-elles des étudiantes? Les filles à l'Université McGill et à l'Université de Montréal (1900-1960)," 593-625.

70. Quoted in Ronald Rudin, "Bargaining From Strength: Historical Writing and Political Autonomy in Late-Twentieth-Century Quebec," in Secession, History and the Social Sciences, eds. Bruno Coppieters and Michael Huyssene (Brussels: VUB Brussels University Press, 2002), 167.

71. Published in English as Quebec: A History, 1867-1929, trans. Robert Chodos (Toronto: James Lorimer and Company, 1983). The authors, this time with François Ricard, followed up in 1986 with the second volume, Histoire du Québec contemporain: le Québec depuis 1930, translated by Robert Chodos and Ellen Garmaise as Quebec since 1930 (Toronto: James Lorimer and Company, 1991).

72. Fernande Roy, Progrès, harmonie, liberté: le libéralisme des milieux d'affaires francophones à Montréal au tournant du siècle (Montreal: Boréal, 1988); Gilles Bourque, Jules Duchastel and Jacques Beauchemin, La société libérale duplessiste, 1944-1960 (Montreal: Les Presses de l'Université de Montréal, 1994).

73. Quoted in Ronald Rudin, "From Nation to the Citizen: Québec Historical Writing and the Shaping of Identity," in Contesting Canadian Citizenship: Historical Readings, eds. Robert Adamoski, Dorothy E. Chunn, and Robert Menzies (Peterborough, ON: Broadview Press, 2002), 103.

74. See Serge Gagnon, Quebec and its Historians: The Twentieth Century, trans. Jane Bierley (Montreal: Harvest House, 1985), 119, 161; Rudin, "Bargaining from Strength," 170-71.

75. There has been a move recently to once again focus on what makes Quebec history different. See Rudin, "From the Nation to the Citizen," 109. There has also been a move beyond "objectivity," see Gérard Bouchard, "L'imaginaire de la grande noirceur et de la révolution tranquille: fictions identitaires et jeux de mémoire au Québec," Recherches 
sociographiques 46, no. 3 (September-December 2005): 432-33.

76. See Micheline Dumont, "Un champ bien clos: L'histoire des femmes au Québec," Atlantis 25, no. 1 (Fall/Winter 2000), 113; Ronald Rudin, Making History in TwentiethCentury Quebec (Toronto: University of Toronto Press, 1997), 195.

77. Éric Bédard, "De la difficulté à penser le conservatisme canadien-français," Recherches sociographiques 46, no. 3 (September-December 2005), 462.

78. Dumont, "Un champ bien clos," 102, 113-14. See also Dumont, "Can National History Include a Feminist Reflection on History?" Journal of Canadian Studies 35, no. 2 (Summer 2000): 80-94; Godin, "Les Yvettes comme l'expression d'un féminisme fédéraliste au Québec," 111; Chantal Maillé, "Québec Women and the Constitutional Issue: A Scattered Group," Journal of Canadian Studies 35, no. 2 (Summer 2000): 95108; Diane Lamoureux, "Féminisme et modernisation," Canadian Woman Studies 20, no. 2 (Summer 2000), 57; Lamoureux, L'amère patrie, 179-81; Rudin, Making History in Twentieth-Century Quebec, 198; Andrée Lévesque, "Réflexions sur l'histoire de femmes dans l'histoire du Québec," Revue d'histoire de l'Amérique française 51, no. 2 (Fall 1997): 279, 283.

79. See, for example, Dorval Brunelle, La désillusion tranquille (Montreal: Hurtubise HMH, 1978); Gilles Bourque and Anne Legaré, Le Québec: La question nationale (Paris: F. Maspero, 1979). On Quebec's integration into the North American economy, see William D. Coleman, The Independence Movement in Quebec, 1945-1980 (Toronto: University of Toronto Press, 1984).

80. On the labour union movement's attitude toward the PQ, see Güntzel, " Rapprocher les lieux du pouvoir'." The Parti Québécois, in fact, has come under intense criticism of late from critics who accuse it of turning its back on the social democratic roots of modern Quebec nationalism. This perception has only increased with the election of the business-oriented André Boisclair as leader. A new party, Québec Solidaire, emerged in February 2006 following the merger of two leftist groups, the Union des forces progressistes and Option Citoyenne, to unite the left in the province against the PQ in the next election.

81. On the struggles between feminists and nationalists, see Mills, "Québécoises Deboutte"' and Lamoureux, "Nationalism and Feminism in Quebec."

82. Some historians highlight the cohesion of the Quebec nation and downplay societal divisions in an effort to remove any distractions on the road to political independence for the province. See Bouchard, "Ouvrir le cercle de la nation," 327. 